\title{
OUTMIGRATION FROM UKRAINE: LOSING BRAINS AND BRAWN
}

\author{
Kiryukhin D. I., \\ $P h D$, Research Scholar, \\ Skovoroda's Institute of Philosophy of the National Academy of Sciences of Ukraine
}

The main goal of the article is to analyze the key trends in temporary labor migration, emigration and the brain drain from Ukraine after 2014. The situation with outmigration from Ukraine is catastrophic today. It's not by chance Franck Düvell calls Ukraine "Europe's Mexico" because, as he states, the level of migration from both countries is comparable. Ukraine would not have experienced such a daunting loss of labor and intellectual resources had the military crisis in Ukraine's East and its economic fallout not coincided with the growing need of the Visegrád Four countries - the Czech Republic, Hungary, Poland, and Slovakia - for a labor force to help develop their economies. Thus both push and pull factors are at work: the conflict with Russia acts to drive migration, while changes in the migration policies of Ukraine's neighbors have opened their labor markets to Ukrainians. Broadly speaking, this two-pronged mechanism accounts for the mass outmigration of Ukrainians since 2014.

The active growth in migration to Russia was observed in 2015-2016, but since 2017, its intensity began to decline. Better opportunities for migrant workers in other countries, particularly Poland, which pays a higher average salary than Russia does, have attracted Ukrainian workers and may be largely responsible for the sharp decline in labor migration to Russia. At the same time, the Visegrád Four countries do not yet have a single coherent migration policy. While countries, such as Poland and Slovakia are generally interested in attracting foreign workers and students, Hungary is focused on encouraging ethnic migration (here the Hungarian policy turns out to be a bit like Russia, which focuses on attracting compatriots), and the Czech Republic, similar to Germany, is oriented toward a highly skilled labor force. Changes in the German migration policy and the growing need for Hungary in the workforce suggest that in the future we will observe a competition for the Ukrainian labor force between Germany and Poland, on the one hand, and between the Visegrád Four countries, on the other.

Key words: outmigration, brain drain, temporary labor migration, Ukraine, Visegrád Four countries, labor market.

Formulation of the problem. High academic mobility is a distinctive feature of the global world, which opens up new opportunities for scientific cooperation and increases the level of scientific research as a result. At the same time, however, under conditions of inter-country economic inequality, facilitating academic mobility does not actually lead to a mutually beneficial exchange (the brain exchange) but to a brain drain from economically disadvantaged countries. However, it would be a mistake to limit the causes of the brain drain exclusively to inequality. A study conducted by Frédéric Docquier, Olivier Lohest, and Abdeslam Marfouk shows that a combination of factors influences the brain drain. Among the most significant are the size of the country (the larger the country, the lower its emigration rates), its geographical proximity to the Organization for Economic Cooperation and Development (OEDC) countries and the level of communication with them (this is, as a rule, the system of relationships that was developed between the former colonies and the metropolis), and, finally, the schooling gap the schooling gap (i.e. "the education level of emigrants compared with natives") and, finally, the sociopolitical environment ("skilled migrants are more sensitive to ethnic and religious tensions") [1, p. 1, 23]. If you look at the significance of these factors in Ukraine, you can see that Ukraine has not been doomed to large-scale brain drain in contrast to areas experiencing highly skilled workers' emigration from Sub-Saharan Africa or South Asian states.

Indeed, Ukraine is a large European country with close humanitarian and economic ties with the postSoviet countries that were formed during Soviet times as opposed to forming ties with the OEDC countries (even though it is geographically close to them) and with a fairly high level of education in the population with low schooling gap [2]. It would seem that there are no structural prerequisites for high migration dynamics of the Ukrainian population. However, the situation is so severe that migration expert Franck Düvell of Oxford University has called Ukraine "Europe's Mexico", [3] in reference to comparable levels of migration from and through both countries. In other words, a fenestrated labor force and the loss 
of intellectual resources as students train abroad for jobs in the EU have placed iron shackles on Ukraine's prospects for future development.

Purpose of the article. The conflict with Russia is a key factor that has determined the sociopolitical environment in Ukraine since 2014. This article intends to consider the impact of this conflict on migration dynamics in Ukraine and in particular, on the brain drain, which not only considers the emigration of scientists and highly educated specialists but also includes students. As we shall see, in the Ukrainian situation for the most talented and active young people, education abroad incorporates the strategy of emigration, not student mobility.

Basic material presentation. Although the problems of emigration in general and of the brain drain, in particular, are quite acute in Ukraine, almost all of the publications on this topic are based on approximate data. Even the representatives of the official authorities of Ukraine, speaking of the number of Ukrainian citizens abroad, call the number from 1 to 3 or even up to 8 million people. These variations are not accidental. First, the social statistics situation is extremely unsatisfactory in Ukraine. The last population census was conducted in 2001. With the Donbass conflict and loss of control over part of the state "s territory, nobody can tell the exact number of citizens living in Ukraine today in addition to the number of those who have emigrated. In addition, Ukraine and the countries of Central Europe and Russia have different statistical systems and methods, and the existing fixation of border crossings does not always allow for determination of the goals of exit and entry (study, high-or low-skilled, seasonal or permanent work, tourism [4, p. 551]). Finally, recipient countries are also experiencing problems with registering Ukrainians. Those are the reasons why we have large discrepancies in the data. For example, the State Statistics Service of Ukraine calculated that in the period from 2015 to 2017, 1303.3 thousand Ukrainian citizens went/were abroad for earning money [5]. Meanwhile, according to data from various Polish sources, in Poland are there from 1 to 2 million Ukrainians (labor migrants, students, and refugees). It is interesting that the Poles themselves do not know the Ukrainians' exact numbers. In order to understand what figure it is, the Polish campaign Selectivv in 2019 studied the behavior of Smartphone owners and concluded that there are $1,270,000$ Ukrainians living in Poland [6]. Besides Poland, Ukrainians go to work in Russia, the Czech Republic, Italy, and Hungary...

The difficulty for the researcher also creates the complexity of the phenomenon of external migration. Indeed, in the Ukrainian case, we are dealing not only with direct emigration and the brain drain but also with seasonal labor, long-term labor, and educational migrations [7, c. 19-21]. Moreover, it is often quite difficult to draw clear lines between these types of migration since in many cases, those who leave for seasonal work abroad then find long-term work, after which they generally do not return to their homeland. These people form the main group of Ukrainian migrants. In this case, that is why we aimed to identify key trends and not a specific number of migrants in a particular state as far as it is almost impossible to calculate them now.

The traditional receiving countries for Ukrainian migrants are Russia, the Visegrád Four countries, Italy, Portugal, the United States (US), and Israel. Moreover, up until 2014, Russia, due to the established historical and economic ties with Ukraine, received almost half of all Ukrainian labor migrants. For example, in $2010-2012,43.2 \%$ of the total number of labor migrants left for this Russia. The rest went mainly to the European Union countries, including Poland (14.3\%), Italy (13.2\%), the Czech Republic (12.8\%), Spain (4.5\%), Germany $(2.4 \%)$, Hungary (1.9\%), Portugal (1.8\%) [8].

Although during the period from 2004 to 2014, Ukraine gradually began to increase the export of labor, and the brain drain began to cause fear because of its negative consequences for the country's economy, the Russia-Ukraine conflict produced such a serious impact on migration processes that only after 2014 can we talk about the beginning of a large-scale exodus of labor and intellectual resources from the country.

Ukraine would not have experienced such a daunting loss of labor and intellectual resources had the military crisis in Ukraine's East and its economic fallout not coincided with the growing need of the Visegrád Four countries - the Czech Republic, Hungary, Poland, and Slovakia - for a labor force to help develop their economies. Thus both push and pull factors are at work: the conflict with Russia acts to drive migration, while changes in the migration policies of Ukraine's neighbors have opened their labor markets to Ukrainians. Broadly speaking, this two-pronged mechanism accounts for the mass outmigration of Ukrainians since 2014.

The main beneficiaries of this situation are Ukraine's neighbors, chiefly Poland and Russia. In February 2018, the influential Polish publication Gazeta Prawna published a list of people who, according to the experts consulted, had had the greatest impact on the Polish economy in 2017. In second place, between Prime Minister Mateusz Morawiecki and President Andrzej Duda, were Ukrainians - "the collective hero of the Polish economy" [9] in the language of the article's authors. Such a dominant position was arrived at in large part through Ukrainians filling the labor force gaps created by Poles emigrating to Western 
Europe to work, which scaled up after the country's accession to the EU [10, p. 150-151]. The influx of workers from Ukraine turned out to be a real salvation for the Polish economy, and the Polish authorities in turn have actively supported this labor migration by relaxing certain legal requirements.

An indication of the strength of the Ukrainian penetration of Poland's workforce is the more than $1,700,000$ work declarations issued to Ukrainian citizens in Poland in 2017, almost eight times the number issued in 2013, just five years earlier [11, p. 6]. Although the pace has slowed somewhat, social conditions, such as strong migrant workers' networks and the low cost of living in Poland, which allows larger remittances to be sent home, are other advantages that help solidify an ongoing Ukrainian presence in Poland's workforce.

Though Russia still receives a considerable population of migrant workers from Ukraine, the number has dropped substantially following Russian actions in Ukraine. Compared with 2013, when Ukrainians received 161,200 permits to work in Russia, in 2015 only 94,700 permits were issued (data from the Federal Migration Service of Russia). This figure does not reflect all Ukrainians working in Russia, since a significant portion work without permits, but even the official figures are very revealing.

The downward trend in labor migration to Russia appears to be solidly based in pragmatism rather than ideology. According to polls conducted in late 2017, 63.2 percent of respondents (adults aged eighteen or older) justified the practice of earning in Russia, in a situation in which Ukraine has officially recognized Russia as an aggressor country [7, c. 14]. Better opportunities for migrant workers in other countries, particularly Poland, which pays a higher average salary than Russia does, have attracted Ukrainian workers and may be largely responsible for the sharp decline in labor migration to Russia.

Unlike Russia and Poland, the migration level to other EU`s countries is significantly lower. For example, data from the Ministry of the Interior of the Czech Republic shows that since 2014 the number of Ukrainians in the Czech Republic has increased but not radically. So, in 2014 in the Czech Republic registered 102,388 Ukrainian migrants, in 2015, the number was 106,019, in 2016, it was 110,245, and in 2017 it was 117480, and, as the researchers note, "Ukrainian nationals represented in 2017 the largest immigrant group in the Czech Republic", moreover, "in the recent years, there was a qualitative change in the migration of Ukrainians to the Czech Republic, as Ukrainian nationals have increased their interest in permanent residence" [10, p. 87].

A similar situation was observed in Hungary. In the period from 2014 to 2017, the number of Ukrainians officially residing in the territory of this country approximately doubled. So, in 2014, there were 7077 Ukrainians in Hungary according to non-humanitarian residence and settlement permits. In 2015, there were 7081, in 2016, there were 7161, and in 2017, the number had already risen to 13,362 [10, p. 237].

At the same time, the Visegrád Four countries do not yet have a single coherent migration policy. For example, a feature of the Hungarian migration policy includes support for the immigration of ethnic Hungarians into the country. In line with that, Budapest supports the acquisition of Hungarian citizenship by Ukrainian Hungarians. Nevertheless, ethnic Hungarians cannot alone satisfy the needs of the growing Hungarian economy, especially because about 9 percent [12] of the working-age Hungarian population words abroad.

This leaves the Hungarian authorities in an extremely difficult situation. Yielding to nationalist sentiment, Viktor Orban's government approved legislation restricting the influx of migrants into the country (primarily aimed at migrants from the Middle East), thereby undermining European solidarity in solving the refugee crisis. At the same time, it has developed legislative measures that give employers the right to require staff to work up to 400 hours in overtime per year (the so-called "slave law"), which caused mass protests in the country. Looking ahead, it's likely that the Hungarian authorities will ease immigration laws for migrants from Ukraine instead of opening borders for Middle Eastern and North African refugees.

As for the Visegrád Four's other countries, Poland and Slovakia are generally interested in attracting foreign workers and students, while the Czech Republic, like Germany, wants a highly skilled labor force. Changes in Germany's migration policy that make it easier for employers to hire foreign workers [13] and Hungary's growing need for workers suggest that in the future, there will be competition for the Ukrainian labor force between Germany and Poland on the one hand, and among the Visegrád Four countries on the other.

Finally, brains follow brawn. Unlike scientists, who mostly go to work in world research centers (therefore, as the State Statistics Service shows, the leaders of countries for emigration of scientists are the United States, Russia, Israel, Germany, and Canada), the directions of educational migration correlates with the directions of labor migration [7, c. 19-22] since 2014. We can explain this by saying that first, many go to study in those countries in which their parents already work, and second, countries that accept labor migrants as a rule are loyal to students. The number of Ukrainian students studying in Poland, Russia, Slovakia, and the Czech Republic significantly increased after 2014. These are also the countries receiving the main flows of labor migration.

Ukrainians who go abroad to study often view their studies as the first stage of emigration. A survey 
of Ukrainian students at universities in Poland, Hungary, and the Czech Republic showed that students who studied in these countries had similar motives for doing so. Most said they intended to earn a diploma in order to work in the EU in the future, since living conditions in Ukraine were unsatisfactory [15]; few planned to return home after graduating [16]. Those who do return may be the ones unable to settle abroad in permanent positions. The negative selection of young specialists - brain drain - is an unwanted consequence of the economic situation currently obtaining in Ukraine. With top-tier intellectual and labor resources leaving the country more or less permanently, Ukraine faces an uphill battle in developing its economy.

Conclusions. Our research shows that the intensification of migration processes in Ukraine, caused by the Russia-Ukraine conflict, has led to an increase in the external migration of Ukrainian citizens in all areas of migration that were formed by 2014. At the same time, under the influence of socio-economic factors, there has been a trend toward the transformation of migration flow, namely, a decrease in the number of migrants going to Russia and an increase in the number of those traveling to EU countries. Between the West and the East, Ukrainians are increasingly making a choice in favor of the West. These choices are not based on ideological reasons but are in response to the situation in the labor market. While Russia's strategy of attracting Ukrainians solves primarily geopolitical and demographic tasks, the Visegrád Four countries have economic tasks followed by political ones (such as attracting Ukrainians instead of opening borders for refugees from Middle East and North Africa). At the moment, the social and economic motivation presented by them becomes more and more significant for Ukrainians, in comparison with the Russian motivation.

The economic consequences of outmigration are mixed. In the short term, the export of labor resources is profitable for Ukraine. It reduces social tensions in the country and makes a significant contribution to the country's budget (in 2017 [17], private transfers from abroad amounted to U.S. \$9.3 billion, four times greater than the amount of foreign direct investment and accounting for approximately 4 percent of Ukraine's GDP). The favorable budgetary bump, among other factors, has allowed Ukrainian authorities to close their eyes to the threats posed by the labor and brain drain. In the long run, however, outmigration, especially if it continues at the current pace, will severely hamper the country's economic development. Ukraine will be in the same situation in which Poland found itself several years ago, when economic development became virtually impossible without attracting foreign labor. But, unlike Warsaw, Kyiv has limited resources to attract labor. This means that Ukraine will not be able to solve the problem simply by opening its labor market to migrants.

Finally, educational migration, the migration policy of Ukraine's neighboring countries, is aimed at attracting highly qualified specialists. A high level of migration attitudes among Ukrainian scientists has caused a significant increase in the brain drain from Ukraine. Today, brawn migration dominates the brain drain from Ukraine. However, it is very likely that in the future, the percentage of talented professionals in the migration flow from Ukraine will increase significantly.

\section{Кірюхін Д. Відтік населення з України: втрата мізків та м'язів}

Головна мета статті - проаналізувати ключові тенденції тимчасової міграції робочої сили, еміграції та відтоку мізків з України після 2014 року. Ситуація з еміграцією з України сьогодні $€$ катастрофічною. Не випадково Франк Дювелл називає Україну «європейською Мексикою», оскільки, за його словами, рівень міграції з обох країн $€$ порівнянним. Україна не зазнала б такої страшної втрати робочої сили та інтелектуальних ресурсів, якби військовий конфрлікт, що триває в Україні, та ії економічний спад не співпали зі зростаючою потребою країн Вишеградської четвірки Чехії, Угорщини, Польщі та Словаччини - у припливі робочої сили задля стимулювання розвитку їхніх економік. А отже, одночасно на міграційну динаміку в Україні чинять вплив як внутрішні, так й зовнішні фактори: конфрлікт із Росією сприяє еміграції, тоді як зміни в міграційній політиці сусідів України відкрили для українців свої ринки праці, що також стимулює від'їзд. Загалом, цей двосторонній механізм пояснює масову еміграцію українців із 2014 року.

Активне зростання міграції в Росію спостерігалося у 2015-2016 роках, а ось із 2017 року іiі інтенсивність починає знижуватися. Найімовірніше, це стало результатом впливу цілого комплексу чинників. Проте головним $€$ те, що в країнах $€ С$ створюються більш сприятливіші умови для робітників з України, зокрема, в Польщі середня заробітна платня працівників-мігрантів $є$ вищою, ніж у Росії. Разом із тим у країн Вишеградської четвірки поки немає єдиної чіткої міграційної політики. Тоді як такі країни, як Польща і Словаччина, в цілому зацікавлені в залученні робочої сили і студентів, Угорщина орієнтована на стимулювання етнічної міграції (тут угорська політика виявляється трохи схожа з російською, яка орієнтується на залучення "співвітчизників»), а Чехія, так само як й Німеччина, - на висококваліфіковану робочу силу. Зміни міграційної політики Німеччини і зростання потреби Угорщини в робочій силі дозволяють припустити, що в майбутньому ми будемо спостерігати 
конкурентну боротьбу за українську робочу силу між Німеччиною і Польщею, з одного боку, і між країнами Вишеградської четвірки, з іншого боку.

Ключові слова: еміграція, відтік мізків, тимчасова трудова міграція, Україна, країни Вишеградської четвірки, ринок праці.

\section{References:}

1. Docquier F., Lohest O., Marfouk A. Brain Drain in Developing Countries. The World Bank Economic Review. 2007. April. 26 p.

2. For developed countries the minimum Education Index is 0.8 , Ukraine's figure as of 2018 was 0.794 . See: Education index. URL: http://hdr.undp.org/en/indicators/103706 (accessed: 11.05.2019)

3. Düvell F. Ukraine - Europe's Mexico? Central and East European Migration, Research Resources Report 1/3: Country Profile. Oxford : Centre of Migration, Policy and Society, 2006. URL: http://www.compas.ox.ac.uk/fileadmin/files/pdfs/Non_WP_pdfs/Transit_Migration_in_Ukraine/ Ukraine Country\%20Report 1of3.pdf (accessed: 27.01.2014).

4. Lendel $\bar{M}$. Migration of Ukrainians to Central European countries in the context of the Postmaidan internal and international crisis. Public Policy and Administration. 2016. Vol. 15. № 4. P. 549-563.

5. Зовнішня трудова міграція (за результатами модульного вибіркового обстеження). Статистичний бюлетень. Київ : Державна служба статистики України, 2017. 36 с.

6. Czubkowska S. Smartfony policzyły Ukraińców. Ile Ukrainek planuje mieć dzieci? URL: http://wyborcza.pl/7,156282,24522397,smartfony-policzyly-ukraincow-ile-ukrainek-planuje-miec-dzieci.html?fbclid=IwAR2LgH1NTCuU6kU1iB8vUXAjJc_t88oLdiQUeAdqzzo9G1MRTQfPZwGQ5ec\&disableRedirects=true (accessed: 22.08.2019).

7. Лібанова Е.М. Зовнішні трудові міграції українців: масштаби, причини, наслідки. Демограсрія та соціальна економіка. 2018. № 2 (33). С. 11-26.

8. Report on the Methodology, Organization and Results of a Modular Sample Survey on Labour Migration in Ukraine. International Labour Organization, Decent Work Technical Support Team and Country Office for Central and Eastern Europe ; (DWT/CO-Budapest). Budapest : ILO, 2013. URL: https://www.ilo.org/budapest/what-we-do/publications/WCMS_244693/lang--es/index.htm (accessed: 02.09.2019)

9. Oto ranking 50 najbardziej wpływowych ludzi polskiej gospodarki. URL: https://biznes.gazetaprawna.pl/ artykuly/1103285, ranking-50-najbardziej-wplywowych-ludzi-polskiej-gospodarki.html (accessed: 22.08.2019).

10. Phantom Menace. The Politics and Policies of Migration in Central Europe. Ed. by Jacek Kucharczyk and Grigorij Mesežnikov. Bratislava : Institute for Public Affairs, Heinrich-Böll-Stiftung, 2018. 268 p.

11. Jaroszewicz M. Migration from Ukraine to Poland: the trend stabilises. Warsaw : OSW, 2018. 18 p.

12. Schaeffer C. Hungary's Workers Are the Victims of a Policy That Limits Migration. URL: https://www.theatlantic.com/international/archive/2019/01/slave-law-hungary-workers-leaving-migrants/580333/ (accessed: 07.02.2019)

13. Zech T. Skilled personnel welcome. URL: https://www.deutschland.de/en/topic/business/the-skilled-labour-immigration-act-working-in-germany (accessed: 07.02.2019).

14. Стадний Є. Українські студенти за кордоном: фракти та стереотипи. URL: https://cedos.org.ua/uk/ articles/ukrainski-studenty-za-kordonom-fakty-ta-stereotypy (дата звернення: 18.01.2019).

15. Ukrainian Students in Czech Republic: Policies of Engagement, Integration, Students' Motivation and Plans; Ukrainian Students in Hungary: Policies of Engagement, Integration, Students' Motivation and Plans; Ukrainian Students in Poland: Policies of Engagement, Integration, Students' Motivation and Plans. URL: https://cedos.org.ua/en/articles/ukrainski-studenty-v-chekhii-polityky-zaluchennia-intehratsii-ta-motyvatsiia-i-plany-studentiv (accessed: 07.02.2019).

16. Кількість студентів з України у Польщі збільшується. URL: http://www.polradio.pl/5/38/ Artykul/384582 (дата звернення: 18.01.2019).

17. Національна доповідь «Українське суспільство: міграційний вимір». URL: https://www.idss.org.ua/ arhiv/Ukraine_migration.pdf (дата звернення: 04.07.2019). 